\title{
Analysing the Institution of Caliphate in the Context of Political Islamists
}

\author{
RECEP DOGAN 1
}

\begin{abstract}
The Caliphate is an important concept for Muslims, especially for those who have been experiencing turmoil, disorder and conflict in their lands, as it presents as a collective body that is to be governed with fairness, assuring safety and justice for all associated with it. Once again it has resurfaced as a hot topic, debated by Muslims and non-Muslims alike. The advent of the 21st century has seen the establishment of many varied initiatives, all in attempt to re-establish the concept of a caliphate, however many of these have been short-lived and have received little support. Gradually, with the declining influence of terrorist organisations, the debate has almost lost its significance. This was until more recently, when the political Islamists of Turkey reignited the discussion through their claims of leader Recep Tayyip Erdogan as the rightful caliph of Muslims, inviting all Muslims to give him their pledge of allegiance. Therefore, it becomes imperative to examine the institution of the caliphate, its relevance to Muslims through identifying the nature of the caliphate and its theological and political values. More importantly, this paper aims to analyse the negative effects of the Justice and Development Party (the AKP) on Muslims, in Turkey and in other parts of the world, as a result of the party's methods of conveying its extreme views through Islamic concepts and extremist religious interpretations. Political Islamists use primary Islamic sources and religious arguments to justify the declaration of caliphate.
\end{abstract}

Keywords: caliphate, Islamic state, Islamism, political Islam, radicalization

The institution of the caliphate has not existed since 1924 when the first Turkish President, Mustafa Kemal Ataturk, abolished it. After the abolishing the caliphate, some groups, including terrorist organizations, attempted to restore this institution. Although the contemporary scholar Ali Abd al-Raziq claims that there is no religious basis for the caliphate either in the Quran or in prophetic traditions (Liebl 2009), it is a fact that many Muslims are looking for a just ruler or a caliph who can unite all Muslims and end all the conflicts among them. The conflicts and wars in the Muslim world are the most likely underlying reason behind many thinking about the notion of a caliphate.

Initially, the Justice and Development Party (AKP) emphasized values of democracy, freedom and human rights. The party advocated the membership in the European Union (EU) to reduce the influence of the military in Turkish politics. However, after continuous success in elections, the AKP has evolved from a broad coalition into a one-man rule. Authoritarian tendencies of the party surfaced when it abandoned the reform processes in line with the European Convention on Human Rights (ECHR) and EU norms. There were a number of reasons for the AKP elite to place a strong emphasis on democracy and human rights. If the party did not respect democracy, secularism and pluralism it would not have had a chance of sustained and effective participation in the Turkish political system. In other words, the AKP needed democracy to defend itself against the radical secularists in the judiciary, in the high levels of the state bureaucracy, in the mainstream media and especially in the military. In order to naturalize the power of the military in Turkish politics, the party regarded the EU as a natural ally.

\footnotetext{
${ }^{1}$ Recep Dogan, Ph.D., lecturer in Islamic Studies at Wisdom College, 97 Formby St, Calamvale QLD 4116, QUEESLAND, Australia, email: drdogan66@gmail.com.
} 
Recep Tayyip Erdogan, the founder of the AKP, is now the only leader who can exercise any real power in the party as well as in the state. To ensure his extraordinary power, he worked with key figures in the media, in politics and in business. He consolidated his power through technocrats whose loyalties were not to the party, but to Erdogan directly and personally. He blocked the legal and legislative steps which were necessary to ensure the state's transparency and accountability. Indeed, even when he was the mayor of Istanbul, he stated that democracy is like a train: you get on the train and when you reach your destination, you get off (Erdoğan 2011). In reality, Erdogan seeks the leadership over Muslims all over the world. In this regard, the institution of a caliphate plays a pivotal role for him to be recognized as the leader of all Muslims.

In order to understand the ideology of political Islamists of Turkey, the opinions of Hayrettin Karaman (2016a), a professor of Islamic Law and long-standing supporter of the AKP Government, issuing his fatwas and interpretations of Islamic rules in accordance with the benefit of the AKP/Erdogan, need to be discussed (Yilmaz \& Bashirov 2018). Karaman argues that in order to abolish the secular system and establish the shariah in Turkey, Muslims should be patient and wait for an appropriate time for action (Karaman 2016a). His logical reasoning for this argument is that if Muslims rush towards bringing shariah to the state, they will cause more problems in society. Through creating a universal leader or a caliph, the idea of Shariah and Islamic state can be actualized. Thus, Karaman supports the caliphate of Erdogan by presenting him as the leader of the ummah (Muslim Community). According to his views, Erdogan possesses all qualifications which are necessary to become the leader of Muslim world (Karaman 2017c). He further argues that when examining Erdogan's words and actions, he appears as the real leader of all Muslims for he advocates not only the rights of Turkish Muslims but also the rights of all Muslims in every part of the world (Karaman 2017a). This description has been demonstrated by Erdogan, as he often calls Muslims to be united against the USA, Israel and Western powers, to prevent their heinous plan of destroying the Islamic world. At this point, he suggests himself as the leader that Muslims should be united around. In return, Karaman called Muslims to protect the leader of Muslims against his enemies (Karaman 2016b). Furthermore, he argued that in order to stop all of the injustices of the superpowers against Muslims, it is a religious duty to listen to Erdogan and be united under his authority (Karaman 2017b). Before the referendum on the amendment of Turkey's Constitution held on April 16, 2017, which opened the way for Erdogan to become a super powerful president, Karaman publicly stated that a "yes vote is an Islamic obligation" (Karaman 2017c).

Any criticism of Erdogan has become a widespread taboo. The notion of a caliphate has been shaped around Erdogan. In order to establish the foundations of the caliphate in Erdogan's person, some terms have been used; "master", "leader", "strong will", "tall man", "chief", "the president of the people", "commander in chief", "leader of the Muslim World" and "the hope of the Ummah" (Gürsel 2014). Erdogan is driven by the logic of a top-down imposition of power. In this regard, the caliphate plays a pivotal role for him to achieve extraordinary power as well as maintain it. He knows that the caliphate can provide him extraordinary power which is uncontrolled, unrestricted, unquestioned and unchallenged. Thus, he promotes the idea that the Muslim world needs a super powerful caliph who can unite Muslims and protect them against the West and the USA. Obviously, his approach has attracted many susceptible masses into his ranks, because, colonialization and occupation of Muslim lands have caused people to expect a leader who can save them. Thus, within the climate of a 'us vs them' dichotomy, Erdogan simply offers himself as the saviour of Muslims.

\section{Definition of Caliph}

The term caliph, khalifa in Arabic, can be translated to refer to one that takes the position of a person, to represent, coming after another in a successive generation, as a proxy and viceregency (Al-Isfahani 1997). Moreover, it means taking the position of over others in order to perform the 
legal and religious rights on their behalf (Ibn Manzur 2005). Generally, in Islamic history, the title of caliph is assigned exclusively to the head of state at the highest level. An alternative word which is used to describe the ruler, or the head of state is amir al-mu'minin, meaning the ruler of believers. The community whom the amir al-mu'minin governs and leads is named the ummah (Muslim community). Moreover, the Arabic word imam similarly defines the ruler of the Islamic state, however the focus of this paper is on the caliph and caliphate. As an Islamic term, caliphate, or khilafah, refers to the Islamic state led by the caliph (al-Isfahani 1997). The word khalifa and its derivations are used in the Quran and Sunnah. In order to understand the concept better, some Quranic verses are given in this section:

Remember (when) your Lord said to the angels: 'I am setting on the earth a caliph (viceregent)' (Qur'an 2:30).

He (God) it is who has made you caliphs (vicegerents or successive generations) on the earth. (Quran 35:39).

O David! We have appointed you a caliph (vicegerent) in the land (to rule according to Our commandments); so, judge among people with the truth and do not follow personal inclination, lest it leads you astray from the path of God (Quran 38: 26).

He (God) it is who has brought you as caliphs (successive generations) to the earth and has exalted some of you over others in degrees (of intelligence, capacity, and then wealth and status): thus, He tries you in what He has granted you (Quran 6:165).

The word khalifah is explained by classical exegeses (Quran commentators) with two meanings; according to the first meaning, human beings are named as khalifah by God for they are created after Jinn and they have taken their positions on Earth (Mawardi 1996). In this regard, human beings are the next conscious beings who have come to the Earth after Jinn, thus, Adam and his progeny are named as khalifah. According to the second meaning, human beings are vicegerents of God on Earth (Razi 2005, 1: 381). They can represent God. In other words, the capacity which is given to humankind has made them so special that they can control nature and the Earth, use them for their own benefits and to contribute their maturation process. Moreover, through learning the names and attributes of God, which are manifested in the universe, human beings can discover many facts by their intellect and use these to build their own civilizations.

Muslim Sufis understand the word khalifa to mean pious servants (Tabari 2010, 24: 117). Ghazali maintains that humankind is so special for God breathed into them His soul. This relation, between God and human beings, is a mystery which cannot be explained by words. Thus, the caliphate of human beings is related to their soul which connects them to God (al-Ghazali 2014, 3: 315). Ibn Arabi believes that the caliph is a perfect human being (Insan-i Kamil) on whom God manifested (perfect human being) His names and attributes in the best way (Ibn Arabi 1996: 50). This perfect human being is the caliph who represents the justice of God on Earth. Although the caliphate is an important concept among Sufis, we will focus more on its religious and political meaning.

\section{The Appointment of Caliphs in Islamic History}

Prophet Muhammad represented many roles in his personal life. He was the Prophet, a ruler, a judge, a commander of the army, a founder of economy, an educator, a father, a husband and many more. While conveying the message of God among people, he ruled in the cosmopolitan state in 
which a community of Jews, paganist Arabs and Muslims accepted him as their leader and ruler. In short, Prophet Muhammad established the foundations of Islamic civilization with the message received from God. During his time of leadership, he combined religious and political missions in his person.

However, the Prophet did not state who would be the head of the state after his death, nor did the Quran assign anyone for this job. In this regard, his wife A'isha states that the Messenger of God passed away while he did not assign anyone as the head of the state after him (Ibn Hanbal 1993, 6: 63). It can be argued that choosing a ruler for Muslims is a political issue and therefore it is left to the people to determine their own rulers. Moreover, the government style is not defined in the Quran, nor in Sunnah, because it can be developed or changed according to the time and conditions.

The election of the first Caliph, or the first ruler after the Prophet, was extremely important for the unity of Muslims due to the political and social conditions of that time. After long discussions, Abu Bakr was elected as the first ruler of susceptible the Muslim population (Ibn Hisham 2013). His title was Khalifatu Rasul al-Allah (Successor of Messenger of God) which can be understood as the ruler who comes after the Prophet. When a person called Abu Bakr "the Caliph of God", he reprimanded him saying "I am Khalifatu Rasul al-Allah" (Ibn Sa'd 1990, 3: 183). It can be argued that Early Muslims never deemed the institution of the caliphate as a sacred role or divine mission, rather they perceived it as a political institution strongly bound to the notion of justice. The first four caliphs, Abu Bakr (632-34), 'Umar (634-44), 'Uthman (644-56) and 'Ali (656-61) have been called as 'the rightly guided caliphs' (Khulafa Rashidin) by Sunni Muslims. The period of the first four caliphs lasted only 29 years (632-661 CE).

The death of the Prophet caused many social and political problems in the nascent cosmopolitan state. The first Caliph Abu Bakr had to fight against rebels who did not want to recognize him as the new ruler and did not want to fulfil their duties towards the state. Abu Bakr successfully handled the problems in his short time in leadership and advised 'Umar as his successor while on his deathbed. Muslims did not oppose his advice and accepted 'Umar as the second Caliph. After ten years of rulership 'Umar was assassinated by a Persian slave in $644 \mathrm{CE}$ but, before his death, he did not proclaim a specific person as his successor. Instead, he appointed a council which consisted of six people to elect the new ruler. The council chose 'Uthman ibn 'Affan as the third Caliph. Uthman's reign was ended by a group of rebels who demanded reforms in the government. They killed the caliph while he was reading the Qur'an at his house. After this tragic event, the Muslim community selected 'Ali ibn Abì Tâlib as their fourth Caliph. When examining the first four caliphs, we see three different methods in their election to the caliphate; public election, designation by a previous caliph and assignment by a council.

The caliphate turned into an inheritance system, passing down from father to son when Mu'awiya, the founder of the Umayyad dynasty, declared his son Yazid as his heir (Tabari 2008, 5: 530-531). This attitude was adopted by almost all Umayyad, Abbasid and Ottoman caliphs and rulers. Political influence of the caliphate was diminished in time. Throughout Islamic history, Muslims obeyed different caliphs and rulers at the same time, while under the rule of various states. In short, there was not a single caliph whom all Muslims gave their pledge of alliance to after the first four caliphs. Indeed, stemming from the time of the third caliph of Islam (Uthman), there have been many conflicts among Muslims with regards to choosing a caliph or ruler and obeying the state. In Islamic history, there was not a single caliph to whom all Muslims gave their pledge of allegiance. For example, when the Ottomans declared the Sunni caliphate, the Safavids, the other Muslim Shiite community, also had their own caliph; they even went to war with each other. 


\section{Is the Caliphate a Religious State or a Political Institution?}

Although the Quran does not use the word khalifah to mean the ruler or head of state, it can be said that the word implies human capacity in general including ruling and governing. The Quran and Sunnah strongly emphasize the notion of justice. They describe the main principles of a just system which a head of state must obey and implement.

The term caliphate connotates that the head of state should rule according to the principles of justice and implement the law among citizens equally. The ruler ensures justice in the state and runs the public affairs in a harmonious manner (Ibn Sa'd 1990, 3: 184). The state is governed through consultation in true sense (shura), so tyranny and authoritarianism can be prevented. Furthermore, citizens whether Muslims or non-Muslims, are supposed to make sure that the ruler and the state are strongly associated with justice, and that they do not violate the rights of any person or any group. Therefore, they need to question the state and the ruler to see if they obey the law and act in line with the principles and objectives of a just system.

The primary sources for an Islamic legal system, as well as the religious laws, are the Quran and Sunnah. Analogical reasoning, general consensus of scholars and many other sources have been used by Muslim scholars to find solutions to problems. Legal systems of each Islamic school of thought, such as Hanafi, Maliki, Shafiii and Hanbali schools, used their own methodology to extract religious rulings from these sources. Qualified scholars are accepted by Muslims as the appropriate authority, able to interpret Islamic sources to establish the law. This task cannot be carried out or controlled by rulers. In other words, scholars are an independent authority that establish the law. Unfortunately, many pious scholars have been persecuted by Muslim rulers due to their opposition to unjust rulers and caliphs. For example, Abu Hanifah, the founder of Hanafi Legal School of Thought, was persecuted simply for refusing to work as a scholar or a judge for the caliph, an attitude that might have implied a certain disapproval of what was taking place.

Islamic civilization can be defined as a civilization of fiqh (jurisprudence), whereby law overrides all that precedes it, making fiqh a highly autonomous body of knowledge. Muslim jurists give a religious legitimacy to political power. As Islam does not require the religious leader, or imam, to be also a political ruler, a caliph, does not have political and religious authority simultaneously.

Although Islamic sources give enough guidance to individuals, including rulers, to be just, they have very little to say on matters of the government and the state. Thus, the form of government, the status of rulers and governmental institutions have been problems for Muslims that need to be discussed and solved by the community. A lack of efficient and successful communication of these issues consequently gave rise to the first serious problem among Muslims: the politics which led to the eventual division of the ummah into Sunnis, Kharijites, Shi' is and other sects.

Because of the political conditions in the Arabian Peninsula, the first four caliphs were chosen from the Quraysh clan. For the first time in the history of Islam, the Kharijites, who separated from 'Ali due to the arbitration incident, argued an independent choice of their own caliph (Shahristani 1948). Choosing a caliph from outside of the Quraysh bloodline is a controversial issue among Muslim scholars. There are two views on this matter. According to the first view, any person who has the necessary qualifications and knowledge of Islamic principles can be a ruler and a caliph (Ibn Hazm 1964). The Kharijite and Mutazilate sects hold this view. The second view many groups maintain is that the caliph must be from the clan of Quraysh.

From a political perspective, there was a public benefit in choosing a caliph from the bloodline of the Quraysh in the early history of Islam. Aware of this fact, Abu Bakr wanted to minimize the conflicts and disputes, and therefore issued his statement regarding the assignment of a caliph hailing from the bloodline of the Quraysh. In order to protect the unity of the nascent Muslim community, the first caliph was chosen from the Quraysh so that other Arab tribes would not dispute it. The task of rulership after the Prophet was not an easy task. As a matter of fact, 
many Arab tribes opposed the new ruler and did not want to pay zakat (tax). However, Abu Bakr successfully subjugated them to his authority and established his ruling on strong foundations.

During the time of the Prophet and the four caliphs, the Quraysh did not have any religious privilege. The first election in the caliphate was a political issue and the Muslims' choice of Abu Bakr was to prevent further conflict in the Muslim society. The following incident shows the mentality of Muslims at that time. A group from Yemen came to Medina upon hearing of the death of the Prophet. When they visited Abu Bakr they said, "O Quraysh, you do not have any privilege against other Arabs, for God did not send His last messenger for the benefit of a specific group" (Ibn Hajar 1970, 5: 91).

Marginal groups in the Kharijite sect hold that Muslims do not need the institution of a caliphate. (Shahristani 1948). The majority in this group believe that a caliphate is necessary for the benefit of Muslims but any Muslim who is qualified to be a ruler, regardless of tribe or background, can be a caliph (al-Ash'ārī 2005). The prominent Ash'ari scholar `Abd al-Qahir Baghdadi (1075-1153 CE) agrees with the Kharijite on this matter, argues that any capable Muslim can be chosen as a caliph (Baghdadi 2017).

Imam Maturidi (d. 944 CE), who is a Sunni imam in Islamic creed, holds that a caliph must be pious, capable of ruling the Muslim community in the best way, wise and with suitable judgement allowing him to make the best decisions in political matters. He states that choosing a caliph must be in line with Islamic principles (Nasafi 1993). Ash'ari scholar Baqillani (950-1013 $\mathrm{CE}$ ) argues that since designation of a caliph is not determined by religious text, it is left to the choice of Muslims (Baqillani 1957).

The famous Muslim historian Ibn Khaldun (1334-1406 CE) argues that the issue of politics and the caliphate is related to representing God's justice among His servants, therefore whoever is capable of providing justice when ruling Muslims should be elected as a caliph (Ibn Khaldun 1967). He analysed the history of the caliphate and argued that at the beginning of Islam, caliphs were chosen from the bloodline of Quraysh and they all tried to provide justice for all the citizens in the state, then it became a kingdom where obeying a caliph was accepted as one of the pillars of Islamic creed (Ibn Khaldun 1967).

Mustafa Sabri Efendi (1869-1954) the last Ottoman Shaykh al-Islam (the Head of Religious Affairs) holds that the caliphate is a religious and political leadership, and a caliph is a person who represents the Prophet (Sabri 1992). Scholars in his line of thought argue that the institution of the caliphate has an honourable place among Muslims and without such an institution, the Islamic world would be considered a community without a head. Mehmed Seyyid Bey (1873-1925), a member of the Grand National Assembly of Turkey between 1923 and 1925, agrees with Mustafa Sabri in the definition of caliphate but disagrees with him in that the institution of the caliphate came to an end after Ali ibn Abu Tâlib, the fourth caliph of Islam (Seyyid 2011). The basis of his argument is on a prophetic tradition: "The caliphate will last thirty years then it will turn into kingdom" (Abu Dawud 2008: Sunnah 9). He believes that the caliphate has a wise purpose, but it follows the requirements of the time, therefore it is the issue of administration and politics. He maintains that when the Prophet died, he did not mention anything about a caliphate to his companions, nor was it mentioned in the Quran (Seyyid 2011).

The notion of tawhid (oneness of God) is an important concept in the caliphate. According to this doctrine, all sovereignty belongs to God alone. However, there is a difference between the real authority and the enforcing authority. The enforcing authority is recognized by the consensus of the Muslim community as the ruler or governor that practices his or her authority according to Islamic principles such as justice and equality. For this reason, in Islam, Muslims are more important than the state because the latter exists only for the welfare of the Muslim community. Since caliphate is a political institution, it cannot be deemed "holy."

However, the religious concept of tawhid (oneness of God) was gradually transformed into a concept of unique, supreme, and absolute power given to the ruler. In other words, religious authority was eventually transposed into political authority in which the ruler possessed 
unrestricted power. In this understanding, the ruler or Sultan owns everything, is capable of everything, and there can be no questioning of his decisions and orders.

Some western scholars assume that the caliph possesses Prophet Muhammed's authority (Feldman 2008) but this is not true. First of all, caliphs or any other persons do not have access to divine revelation, for Prophet Muhammed is the seal of the prophets, thus, there is not any other prophet whom all Muslims are required to obey. As such, caliphs or rulers lack the religious authority which requires absolute obedience. Furthermore, Prophet Muhammad upheld a variety of positions in his personal life such as being a judge, a ruler, a prophet, a role model, and more. In this regard, Muslims have never seen anyone equal, in importance and influence, to the Prophet. Moreover, there is no evidence in the Quran or in Sunnah that caliphs can be regarded as representatives of the Prophet.

The insurgency of Kharijites against the caliph Ali, the battle of Siffin between Mu'awiyah and Ali and the battle of Jamal between Ali and some prominent Companions of Prophet including Aisha, the wife of the Prophet, indicate that the caliphate was a political matter. If the caliphate was a religious institution, Muslims could not disobey the caliph, nor would they disagree with him. Indeed, caliphs were the leaders who came after the Prophet to rule the Muslim community. However, since early times, the Islamic community has split into many groups and there have been severe disputes and disagreements among Muslims. Some groups, including extreme ones, have attempted to unite Muslims under the caliphate by changing its meaning from a political institution to a religious one.

\section{Contemporary Groups Which Aim to Revitalize the Caliphate}

The reformist scholar Abu al- 'A'la Mawdudi (1903-79) expressed the need for a caliphate in his books to revive the way of Islamic life (Mawdudi 1967). In 1925, Taqiuddin al-Nabhani (190979), established the Hizb ut-Tahrir (Party of Liberation) in Jordan to revitalize the institute of caliphate (McQuaid 2007) but he did not succeed. Sayyid Qutb (1906-66), an Egyptian scholar who spent at least ten years in prison, believed that the values of the Quran are valid for all humanity all the time and that the world must inevitably submit to Islam under a universal caliphate (Qutb 1975). However, their call to the caliphate did not attract much attention in the Muslim world for Muslims were struggling with socialism, communism and capitalism during that time.

In 1996, Mullah Mohammed Omar, the leader of the Taliban, announced himself as the amir al-mu'minin and tried to revitalize the caliphate in his person. His attempt was recognized by Usama bin Laden, who pledged his personal loyalty to him as the legitimate ruler of the state of Afghanistan (Scheuer 2005). Nevertheless, the caliphate of Mullah Mohammed Omar was not recognized by the general Afghan population. In order to convince Muslims of the need of a caliphate, Usama bin Laden and Ayman al-Zawahiri used the concept of jihad under leadership of the caliph. In 1998, they co-signed a fatwa in the name of the 'World Islamic Front for Jihad Against Jews and Crusaders' which declared the killing of Americans and their allies in order to liberate the al-Aqsa Mosque in Jerusalem and the holy mosque in Mecca (Liebl 2005).

The Quran and the Sunnah do not mention the caliphate as a governing system of Muslims, but rather they provide general principles, higher objectives and guidelines for Muslims to establish their own governments and states according to their time and conditions. This flexibility in the interpretation of Islamic sources is exploited by extremists and terrorist groups. For example, in mid-2006, Al-Qaeda declared that the Iraqi city of Ramadi as the capital of the new Islamic caliphate (Fletcher 2007). ISIS was another terrorist group which declared a caliphate in an area straddling Iraq and Syria and announced their leader, Abu Bakr al-Baghdadi, as the caliph (Weaver 2014). 
Although ISIS claimed its desire of unifying Muslims under its caliphate in an attempt to mask its violence and terror, its claim directly contradicted Islamic faith and historical facts. Islam never permits anyone or any group to promote violence and terrorism. Instead of uniting Muslims, ISIS has been killing Muslims and non-Muslims to establish its so-called "Islamic state." They declared other Muslims as apostates and then legitimized their bloodshed. According to the Quran and Sunnah, the ruler is required to provide justice among all citizens. He must prevent cruelty, wrong doings and injustices during his rule. When examining the caliphate of ISIS, we see only terror, violence, disunity and evil acts. So, it can be argued that any extreme group such as ISIS who uses the concept of a caliphate is indeed trying to cover up its cruelty and legitimize its violence. Therefore, the caliphate is a political institution, that has been exploited by extreme groups with religious arguments. If Muslim scholars do not explain this fact clearly, the susceptible masses will continue to be radicalized by extremists.

\section{Turkey: From Democracy to One-Man Rule and Its Connection with the Caliphate}

After the July 15 coup attempt in 2016, Erdogan took over all the power in Turkey under the guise of a counterterrorism tactic. The rule of law in Turkey has been suspended with decrees taken under the state of emergency. The AKP regime, or the Political Islamists of Turkey, have granted impunity to Erdogan to take the law into his own hands. More recently, political Islamists have been using the power of law against their opponents. Unfortunately, this has led to the transition of Turkey from a NATO ally to an aggressive and tyrannical state. Moreover, Islamic radicalism and extremism have increased during the rule of AKP. Thus, the essay argues that political Islamists of Turkey have perhaps become the most serious threat to the world due to their extreme views and their ability to convince masses to accept their ideology. This shift has become more evident in recent years, where Turkey is increasingly being represented as an unprecedented external and internal challenge to the US and Europe.

\section{Call for Jihad under the Leadership of a Caliph}

There has been an intensifying force of hostility in the policies of AKP, both domestic and foreign, towards America and the west. Under the rule of political Islamists, the political system in Turkey has become authoritarian. The party has been trampling Turkey's constitution. Muslims in Turkey, as well as in other parts of the world, have become more radical due to the great effect of political Islamists and their extreme ideology. As such, they speak openly of engaging in "jihad" and a revival of the Ottoman Empire under the institution of a caliphate.

Berat Albayrak, Minister of Finance and Treasury in the AKP cabinet, stated that the army was doing jihad in Afrin against Syrian Kurds and "we (political Islamists) are preparing for the jihad in election of 2019, may God bless our jihad" (Diken 2018). Indeed, Erdogan himself declared jihad against Syrian Kurds, and then religious preachers gave sermons justifying the assault as a holy war (Kajjo 2018). Jihadist groups are now forcing non-Muslim minorities in Afrin to convert to Islam.

The Turkish military has interfered with the battle in Syria and seized territory from Kurdish militias. In January 2018, Ismail Kahraman, the Speaker of Turkey's National Assembly, called Muslims to jihad against Syrian Kurds saying that there can be no progress without jihad (Hayward 2018). A few weeks later, Erdogan warned Cyprus and Greece over disputed gas fields in the Mediterranean Sea, stating that "their courage persists only until they see our army, our ships and our planes" (Reuters 2018).

Political Islamists have strong relations with radical groups such as IS or ISIS. Although they have denied that they were helping IS, Turkish journalists exposed their aid to the terrorist group and were then promptly arrested by authorities (Norton 2016). When Mohamed Morsi won general elections in 2012, Erdogan visited Egypt swiftly and advised him not to move too 
quickly on imposing a full implementation of Shariah. This is because he sees himself first and foremost as a Muslim leader or the caliph of Muslims who should therefore give advice to all Muslims when necessary. When the United States recognized Jerusalem as Israel's capital in 2017, Erdogan threatened to break relations with the US and Israel, claiming that Jerusalem is a "redline" for all Muslims (Aljazeera 2017). Thereupon, Muslims in America protested against Trump shouting "Recep Tayyip Erdogan, the true leader of the Ummah (Muslims)" (Allahverdi 2017).

The radical approach of Erdogan in his politics and leadership has been affecting Muslims negatively all over the world. This is the result of Erdogan's caliphate claim for he argues that he has the right and authority to intervene in any situation which involves Muslims in the world. He openly supports HAMAS and in return, HAMAS has pledged its fidelity to Erdogan. The Diyanet Center of America (DCA), was formally opened in Lanham, MD in April 2016, with Turkish President Recep Tayyip Erdogan in attendance for the ribbon cutting ceremony. Erdogan and the AKP have established strong ties with Muslim Brotherhood organizations in the US. The United States Council of Muslim Organizations (USCMO) is a Muslim Brotherhood organization in the US that directs initiatives and programs through the Diyanet Center of America, for advancing the Muslim Brotherhood and its civilization Jihad on U.S. soil (Gafney n.d.). Moreover, the DCA serves as a front for the Turkish Government, and maintains a close, strategic relationship with the Muslim Brotherhood leadership at the All Dulles Area Muslim Society (ADAMS) Center (The Diyanet 2017).

Under the leadership of Erdogan, political Islamists have been supporting Muslims in Europe in establishing their own political parties. Across Europe, Muslims who have been inspired by Erdogan have established their own political parties such as the DENK party in the Netherlands, the Equality and Justice Party (PEJ) in France, and the NBZ Party in Austria (Joffe 2017). The AKP organizes Muslims in Europe to allow them to achieve political power, so they in turn may support the caliphate of Erdogan. Erdogan therefore is able to influence Europe through controlling and leading its Muslim population. For example, the Equality and Justice Party (PEJ) in France is Erdogan's hand in France (Gozlan 2017). The NBZ Party, which gives Turks a voice in politics across Austria, supports Erdogan publicly (Tomlinson 2017). Similarly, the Netherland's DENK party has been accused of being a mouthpiece of Erdogan (Mansfield, 2017).

\section{Caliphate of Erdogan and Political Islamists' State}

Political Islamists try to articulate their ideology in response to society's current political, economic and cultural problems (Dogan 2018). They argue that Islam is a divine system which can be used anywhere and at any time. It is perceived as superior to other political systems with its ability to respond to all dimensions of human problems. However, interpreting Islam and its sources according to time and conditions require a group of scholars (mujtahids) who are moderate and who can produce realistic solutions to promote world peace. Otherwise, this claim remains a political slogan which only contributes to the radicalization process of Muslims.

Political Islamists champion the idea that Muslims must be united politically under one leader, the caliph of Muslims (Haber 2017). They argue that when united under the banner of AKP, Muslims can establish an Islamic government which is governed by Shariah (Karaman 2017b). They invite all Muslims to work for the interests of the Ummah constantly because it has been facing severe opposition from the west and non-Muslims (Karaman 2015). As a stark opponent to political Islamists, Fethullah Gülen argues that the Ummah is more of a transnational sociocultural entity which will be instrumental in bringing general universal peace (Yilmaz 2003: 235). However, in a rather contradictory manner, political Islamists blame all other Muslims as blind imitators of the West while they alone stand for the truth (Karaman 2015). They claim that they convey the true message of God while other Muslims serve for the interest of the West. They have used nationalist discourse to demonize and criminalize their opponents (Yilmaz \& Bashirov 2018). 
The idea of establishing a caliphate and Islamic state looks attractive today to Muslims who have been persecuted by internal tyrannical regimes. The appeal of a socially conservative religion in an uncertain world, and the yearning for spiritual revitalization makes the concept desirable for the oppressed Muslims. The hope for a better future in terms of religious freedom and expression of Muslim identity has been exploited by politicians for their own political agendas. Particularly in the Middle East, where dictatorships and monarchies have failed to bring peace to the region, many see that the governments in Muslim countries are in desperate need of reform. In this regard, the idea of establishing an Islamic state which will be governed by the laws of Shariah comes to the fore.

Outside of the Arabian Peninsula, the ideas of political Islam have made their way and are targeting Muslims in countries where they constitute as minorities. Such is the case in India, where the Hindu identity is moving towards being the national identity, leaving the Muslim population more susceptible to accepting ideas of pan-Islamism. Moreover, when prominent religious icons, such as Dr. Zakir Naik, vocalize their support of Erdogan's movement, the motion of political Islamists gains momentum as those that trust these preachers will submit to the political inclinations of these individuals (Zakir Naik 2017). Moreover, the technological advancement of the modern era further accelerates this expansion of support, allowing those not near the Middle Eastern region to connect to and appreciate the notion of a global caliphate by submitting with a virtual following. This particularly has an impact when vulnerable youth in Western countries, disconnected from the general population, finds refuge in the idea of being part of a state that cements their religious identity and joins them with other individuals, diasporic or otherwise, in furthering the cause of political Islam.

It is apparent, then that political Islamists solidify their claim by advocating the idea of an Islamic state as a solution for Muslims for their problems (Karaman 2013). However, this comes as a superficial motion, as they do not clearly explain how they could offer solutions for deep problems of political dysfunction and economic stagnation.

\section{Interpreting Islamic Sources in Favour of a Caliphate and Islamic State}

Islam emerged in a tribal society where Prophet Muhammad established a multi-faith and multicultural state. As previously mentioned, the Quran does not stipulate a specific form for the state or the government, nor does the Sunnah, and Prophet Muhammad did not appoint a successor after himself even though he knew his death was imminent. As such, a unanimous single body into which all citizens would be accepted, would act collectively in enforcing social order and security, and in confronting enemies in times of war and peace. The Prophet did not exclude nonMuslims and multiple religious communities from the state. Contradicting the very method of the Prophet, political Islamists of Turkey exclude all opponents who disagree with their ideology.

The act of establishing an Islamic state is mixed with a call for a return to the Shariah. Many extreme groups use the concept Shariah to convince Muslims of their cause. This is because Shariah invokes the core idea of law in terms that resonate deeply with the Islamic past. Thus, an Islamic state is pre-eminently a shariah state which is defined by its commitment to a vision of legal order (Brown 1997: 11) However, the very word Shariah conjures images of social control through severe criminal punishment.

Political Islamists argue that it is a religious duty to obey the caliph (Dogan 2018). If any person or group disobeys him, they are eliminated for the benefit of society. In order to protect the unity and harmony of Muslims, all opponents must be eradicated by the state (Kenes 2018). Since Erdogan is the proposed caliph, all Muslims should give a pledge of alliance to him and obey his order without questioning his authority (Yilmaz \& Bashirov 2018). Political Islamists use some Quranic arguments to support Erdogan such as, "O you who believe! Obey God and obey the Messenger, and those from among you who are invested with authority... " (Quran 4:59). The 
Arabic word ulu'l amr translates to those are invested with authority and is understood by political Islamists to refer to the ruler whom all Muslims must obey.

Contrasting their interpretations on the matter, the Quran states that all public duties and positions are given to those who are qualified, but not to those who are corrupt and oppressive. The ruler and other officials must ensure justice in public affairs and judgment. Indeed, Prophet Muhammed stated that "there is no obedience in sin or rebellion against God" (Bukhari 1997). Violating basic human rights by putting thousands of people in jail, including women with their infants due to their sympathy to the Gülen movement or due to their opposition to the AKP regime, is a blatant disobedience to God. It is a great paradox that political Islamists seek obedience from citizens to the ruler despite his violations of the basic principles of Islam such as provision of justice to all citizens equally. Another argument which Political Islamists use the hadith of the Prophet, which states "God will raise for this Ummah at the beginning of every hundred years, one who will renovate religion (Abu Dawud 2008, Malahim 1). The Arabic word mujaddid, which means "the one who renovates religion", is used by Political Islamists as an argument to support the caliphate of Erdogan. In spite of all injustices and oppression, Bakir İzzetbegovic argued that Erdogan is the renovator of religion in our time (İzzetbegovic 2018). There are many more religious arguments which have been used by political Islamists to support Erdogan, but it is beyond the scope of this article to present all of them here.

To conclude, political Islam is the new face of religious extremism in 21th century. It is far more effective than previous attempts, particularly on the susceptible masses in terms of their radicalization, as the representatives of this ideology use religious concepts to successfully reach their goals. They emphasize the attributes of a caliphate, the notion of an Ummah and Islamic state, to convince Muslims to accept their extreme ideology. Among many Muslims, not only in the Islamic world but also in other places, there is support for the extreme ideology of political Islamists. Although the prominent view on the caliphate is that it cannot be revitalized because of the establishment of nation states and the development of ideas of independence Muslims in America, Europe, Australia and many other places are increasingly accepting the notion of a global caliphate and this presents a serious threat for the world peace in the near future.

\section{References}

Abu Dawud, S.I.A. 2008. Sunan Abu Dawud. Beirut: Dar al-Kutub al-Ilmiyah.

al-Ash'ari, A.H. 2005. Maqalat al-Islamiyyin. Cairo: Maktabat al-Thaqafah al-Diniyah.

Aljazeera. 2017. Erdogan: Jerusalem status a red line for Muslims. https://www.aljazeera.com/news/2017/12/erdogan-jerusalem-status-red-linemuslims-171205070449352.html. Retrieved: December 5, 2017.

Allahverdi, S. 2017. Thousands in Washington protest US Jerusalem decision. https://www.aa.com.tr/en/americas/thousands-in-washington-protest-us-jerusalemdecision/1007136. Retrieved: December 17, 2017.

Allahverdi. 2017. https://www.aa.com.tr/en/americas/thousands-in-washington-protest-usjerusalem-decision/1007136). Retrieved: December 29, 2017.

Baghdadi, A.Q. 2017. Usul al-Din. Cairo: Maktabat al-Thaqafah al-Diniyah

Baqillani, M. 1957. Kitab al-Tamhid. Beirut: al-Maktabah al-Sharqiyah.

Brown, N. 1997. The Rule of Law in the Arab World: Courts in Egypt and the Gulf. Cambridge: Cambridge University Press.

Diken, Gazanız mübarek olsun: Bakan Albayrak'a göre AKP teşkilatı seçim savaşına hazırlanıyor. http://www.diken.com.tr/gazaniz-mubarek-olsun-bakan-albayrak-teskilatimiz-secimsavasina-hazirlaniyor/. Retrieved: April 15, 2018.

Diken. 2018. http://www.diken.com.tr/gazaniz-mubarek-olsun-bakan-albayrak-teskilatimizsecim-savasina-hazirlaniyor/). Retrieved: May 5, 2018.

Dogan, R. 2018. Political Islam (The Justice and Development Party in Turkey) Versus the Gülen Movement. Journal of Social Science Studies. 5(2): 89-105. http://doi.org/10.5296 
/jsss.v5i2.13126.

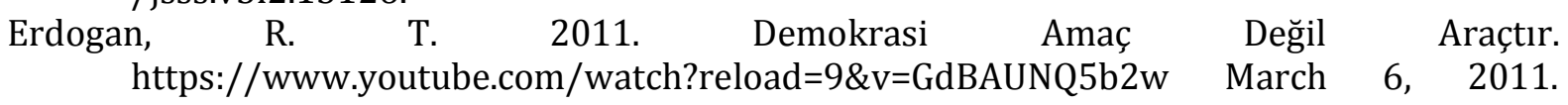
Retrieved: April 17, 2018.

Feldman, N. 2008. The Fall and Rise of the Islamic State, Princeton: Princeton University Press.

Fletcher, M. 2007. How Life Returned to the Streets in a Showpiece City that Drove out Al Qaeda. https://www.thetimes.co.uk/article/how-life-returned-to-the-streets-in-a-showpiececity-that-drove-out-al-qaeda-dq0gfbcmgqp. Retrieved: August 31, 2007.

Gaffney, F. n.d. Center for Security Policy. "The Muslim Brotherhood in America". https://www.centerforsecuritypolicy.org/the-muslim-brotherhood-in-america/. Retrieved: May 18, 2018.

al-Ghazali, A.H. M. 2014. Ihya al-Ulum al-Din. Kuala Lumpur: Pustaka Al-Shafa.

Gozlan, M. 2017. La main d'Erdoğan dans les urnes de France: 68 candidats du PEJ aux législatives," Marianne. https://www.marianne.net/politique/la173main-d-Erdoğandans-les-urnes-de-france-68-candidats-du-pej-aux-legislatives. Retrieved: January 19, 2018.

Gürsel, K. 2014. The Cult of Erdoğan. Al Monitor. 6 August 2014. http://www.almonitor.com/pulse/originals/2014/08/gursel-turkey-social-peaceErdoğan-cult-polarization-akp.html. Retrieved: May 18, 2018.

Haber, Samanyolu. 2017. http://www.shaber3.com/gulen-firkasi-halifeye-biat-etmedi-devletinyaptiklarini-hak-ediyor-haberi/1288894/). Retrieved: January 17, 2018.

Hayward, J. 2018. Speaker of Turkish National Assembly Declares 'Jihad' Against Kurds. http://www.breitbart.com/nationalsecurity/2018/01/29/speaker-turkish-nationalassembly-declares-jihad-kurds/. Retrieved: January 29, 2018.

Ibn Arabi, M. 1996. Fusus al-Hikam. Beirut: Dar al-Kitab al-'Arabi.

Ibn Hajar, A. 1970. al-Isaba fi Tamyiz al-Sahaba. Egypt: Dar Nahdat.

Ibn Hanbal, A. 1993. Musnad. Beirut: Mu'assasat al-Risalah.

Ibn Hazm, A. 1964. Kitab al-Fasl fi al-Milal wa-al-Ahwa' wa al-Nihal. Baghdad: Maktabat alMuthanna.

Ibn Hisham, A. 2013. The Life of Muhammad. New York: Oxford University Press.

Ibn Khaldun. M. 1967. Muqaddimah. trans. F. Rosenthal. Princeton, NJ: Princeton University Press. Ibn Manzur, M. 2005. Lisan al-Arab. Lebanon: Dar Al-Kutub.

Ibn Sa'd. M. 1990. Tabaqat al-Kubra. Beirut: Dar al-Kutub al-'Ilmiyah.

al-Isfahani, R. 1997. Mu'jam Mufradat Alfaz al-Quran. Beirut: Dar al-Kutub al-Ilmiyyah.

İzzetbegovic, $\quad$ B. 2018. Erdogan is Renovator of Religion. https://www.dailymotion.com/video/x6k0x12. Retrieved: May 22, 2018.

Joffe, A.H. 2017. Europe's Red-Green Alliance: A Dystopian Scenario. Middle East Forum. http://www.meforum.org/7037/europes-redgreen-alliance. Retrieved: November 26, 2017.

Kajjo, Sirwan. 2018. Turkey in Syria: Ruling Kurdish Afrin by Sharia Law, Ethnic Cleansing. Available online: https://www.gatestoneinstitute.org/12269/turkey-syria-afrin-sharia. May 13, 2018.

Karaman, H. 2013. Türkiye'nin dostları ve düşmanları. http://www.yenisafak.com/yazarlar/HayrettinKaraman/turkiyenin-dostlari-vedusmanlari-44456. Retrieved: Dec 19, 2013.

Karaman, $\quad$ H. $2015 . \quad$ Birlik ve huzur düşmanları. https://www.yenisafak.com/yazarlar/hayrettinkaraman/birlik-ve-huzur-dumanlari-22021818. Retrieved: April 13, 2015.

Karaman, H. 2016a. Anayasa ve laiklik tartışmaları https://www.yenisafak.com/yazarlar/hayrettinkaraman/anayasa-ve-laikliktartimalari-2-2028889. Retrieved: May 8, 2016.

Karaman, $\quad$ H. 2016b. Bu $\quad$ niçin? https://www.yenisafak.com/yazarlar/hayrettinkaraman/bu-ittifak-nicin-2029126. 
Retrieved: May 19, 2016

Karaman,

$\mathrm{H}$.

$2017 \mathrm{~b}$

Gözyaşlarımız

aynt. https://www.yenisafak.com/yazarlar/hayrettinkaraman/gozyaslarimiz-ayni-2040255. Retrieved: September 22, 2017.

Karaman, $\mathrm{H}$. 2017c.

Neyi

oyluyoruz? https://www.yenisafak.com/yazarlar/hayrettinkaraman/neyi-oyluyoruz-2037309. Retrieved: April 13, 2017

Kenes, B. 2018. Instrumentalization of Islam: Hayrettin Karaman's Role in Erdogan's Despotism. http://www.politurco.com/instrumentalization-of-islam-hayrettin-karamans-role-inerdogans-despotism.html. Retrieved: May 30, 2018.

Liebl. V. 2009. The Caliphate. Middle Eastern Studies 45(3): 373-391.

Mansfield, K. 2017. Trouble brewing in Netherlands as Erdoğan supporters win first seats in Dutch election. Express (UK). https://www.express.co.uk/news/world/779891/dutchelection-turkish-dutch-partydenk-win-first-seats-netherlands-parliament. Retrieved: March 16, 2017.

Mawardi, Muhammad bin Habib. 1996. Al-Ahkam al-Sultaniyyah. Beirut: Dar al-Kutub al-Ilmiyyah. Mawdudi, A.A 1967. Islamic Way of Life. Delhi: Markazi Maktaba Islami.

McQuaid, J.V. 2007. The Struggle for Unity and Authority in Islam: Reviving the Caliphate? Alexandria, VA: CNA Center for Strategic Studies.

Nasafi, M. 1993. Tabsirat al-Adilla. Ankara: Diyanet Isleri Baskanligi Yayinlari.

Norton, B. 2016. Turkey's "double game" on ISIS and support for extremist groups highlighted after horrific Istanbul attack. https://www.salon.com/2016/06/30/turkeys_double_game_on_isis_and_support_for_e xtremist_groups_highlighted_after_horrific_istanbul_attack/. Retrieved: June 30, 2016.

Qutb, S. 1975. Social Justice in Islam. Beirut: Dar al-Shuruq.

Razi, Fakhr al-Din. 2005. Tafsir al-Kabir. Beirut: Dar al-Fikr.

Reuters, Erdogan tells Cyprus not to test Turkey over gas standoff. https://www.reuters.com/article/us-cyprus-natgas-turkey/erdogan-tells-cyprus-notto-test-turkey-over-gas-standoff-idUSKBN1FX0XZ. Retrieved: February 13, 2018.

Reuters. 2018. https://www.reuters.com/article/us-cyprus-natgas-turkey/erdogan-tellscyprus-not-to-test-turkey-over-gas-standoff-idUSKBN1FX0XZ). Retrieved: March 5, 2018.

Sabri, M. 1992. Hilafet ve Kemalizm. Istanbul: Arastırma Yayınları.

Seyyid, M. 2011. Usul-i Fıkıh: Medhal. Istanbul: Kitap Yurdu.

Shahristani, M. 1948. al-Milal wa al-Nihal. Cairo: Maktabat al-HHusayn al-Tijariyah,

Tabari, Muhammad ibn Jarir. 2008. Tarikh al-Umam wa al-Muluk. Beirut: Dar al-Kutub al-'Ilmiyah.

Tabari, M. I. J. 2010. Jami' al-Bayan 'an Tafsir Ayat al-Qur'an. Cairo: Dar al-Hadith.

The Diyanet. 2017. Coordination Meeting with Turkish Religious Leaders (Imams). https://diyanetamerica.org/news/coordination-meeting-with-turkish-religiousleaders-imams/. Retrieved: March 21, 2017.

Tomlinson, C. 2017. Turkish Migrants Form New Political Party in Austria. Breitbart London, http://www.breitbart.com/london/2017/01/17/migrantsform-political-party-austria/. Retrieved: January 17, 2017.

Weaver, M. 2014. Isis declares caliphate in Iraq and Syria. https://www.theguardian.com/world/2014/jun/30/isis-announces-islamic-caliphateiraq-syria. Retrieved: June 302014.

Yilmaz, I. 2003. Ijtihad and Tajdid by Conduct The Gülen Movement. Ed. M Hakan Yavuz \& John L Esposito N.Y.: Syracuse University Press.

Yilmaz, I., \& Bashirov, G. 2018. The AKP after 15 Years: Emergence of Erdoganism in Turkey. Third World Quarterly. 39 (9): 1812-1830.

Zakir Naik. 2017. https://www.youtube.com/watch?v=HAg5zM-CCfI). Retrieved: June 4, 2017. 